\title{
Analysis of Heavy Metal Content in the Coral Reef and Foraminifera Benthic in Coastal Regions of Lampung Bay
}

\author{
Endang L. Widiastuti ${ }^{1,3,{ }^{*}}$ Benny $^{1}$ R. Supriyanto ${ }^{2}$ Eva Octarianita ${ }^{1}$
}

\author{
${ }^{1}$ Department of Biology, Universitas Lampung, Bandar Lampung, Indonesia \\ ${ }^{2}$ Department of Chemistry, Universitas Lampung, Bandar Lampung, Indonesia \\ ${ }^{3}$ Coastal and Marine Research Center, Universitas Lampung, Bandar Lampung, Indonesia \\ *Corresponding author.Email:elwidi@yahoo.com
}

\begin{abstract}
Coral reefs and benthic foraminifera are efficient pollution bioindicators for predicting heavy metal pollution due to their great tolerance to high ecological pressures, so that these biota are used as test animals in monitoring the accumulation rate of heavy metals of marine waters. The purpose of this study is to determine the heavy metal consentration, such as Silver (Ag), Cadmium $(\mathrm{Cd})$, Cobalt $(\mathrm{Co})$, Cromium $(\mathrm{Cr})$, Copper $(\mathrm{Cu})$, Iron (Fe), Manganese Mn), Nickel (Ni), Lead ( $\mathrm{Pb})$ and Zinc $(\mathrm{Zn})$ on benthic biota, foraminifera and hard corals of lampung bay Coastal Waters by using the ICP-OES (Inductively Coupled Plasma-Optical Emission Spectrometry). Samples were analyzed in integrated biomass laboratory of the University of Lampung.

The results of the study obtained on coral reef samples taken from the three locations refer to the Heavy Metal Standard in Sediment only of Ag metal which passed the standard of Metals according to the Regulation of the Governor of DIY (Daerah Istimewa Yogyakakarta). 7 of 2010 , with an average $(0.42 \mathrm{mg} / \mathrm{kg}),(0.19 \mathrm{mg} / \mathrm{kg}),(0.23$ $\mathrm{mg} / \mathrm{kg}$ ). when passes the standard were $\mathrm{Ag}, \mathrm{Cd}, \mathrm{Cr}, \mathrm{Cu}, \mathrm{Fe}, \mathrm{Mn}, \mathrm{Ni}, \mathrm{Pb}$ and $\mathrm{Zn}$. for thes Foraminifera samples heavy metal consentration exceeding the quality standard in the sediment was Ag, colected from Sari Ringgung and Tegal island, with the consentration of $0.250 \mathrm{mg} / \mathrm{kg}$ and $0.161 \mathrm{mg} / \mathrm{kg}$. when to the standard of metal in Sea water for heavy metal biota that passes the standard quality standards are $\mathrm{Ag}, \mathrm{Cd}, \mathrm{Cr}, \mathrm{Cu}, \mathrm{Ni}, \mathrm{Pb}$ and $\mathrm{Zn}$.
\end{abstract}

\section{Keywords: Coral Reef, Foraminifera, Heavy Metal, ICP-OES, Lampung Bay}

\section{INTRODUCTION}

Indonesia is a maritime country that has a wider territorial waters in the appeal of its land area. Indonesia is also known as the center of world's coral triangle (The Coral Triangle) in which there are various kinds of coral reefs lying scattered throughout the Indonesian waters, extensive coral reef in Indonesia reached $50,000 \mathrm{~km} 2$ and almost $25 \%$ of coral reefs in the world , Indonesia's coral reefs amount to about 7080 and more than 500 species that are part of the $70 \%$ of coral diversity in the world [1].

Coral reef ecosystems are part of the marine ecosystem is important because the source of life for diverse biota laut.Terumbu coral has a very important function as spawning, feeding, care area for marine life, as a source of germplasm, as well as coastal protection from degradation and abrasion [1]. Foraminifera included in the phylum Protozoa that began to develop in theAge Cambrian until Resen.The majority of members live onthe marine environment and have a size ranging from $3 \mu \mathrm{m}$ to $3 \mathrm{~mm}$ [2]. According habitat, divided into foraminifera planktonic foraminifera and benthic foraminifera.
Marine waters is where the flow of water from the mainland leads through rivers and canals. Thus the sea into a gathering of various contaminants which brought the water flow. These wastes are carried out to sea and further pollute the ocean [3]. The heavy metal is one element of water pollutants that are toxic and must be wary of its existence [4].

Sari ringgung beach, Tegal islands and tarahan is vulnerable to water pollution because their place adjacent to the industry and the busy waters with ship traffic. So necessary to study heavy metal content silver ( $\mathrm{Ag})$, Cadmium $(\mathrm{Cd})$, cobalt $(\mathrm{Co})$, Chromium $(\mathrm{Cr})$, Copper $(\mathrm{Cu})$, iron $(\mathrm{Fe})$, manganese $(\mathrm{Mn})$, nickel $(\mathrm{Ni})$, Lead $(\mathrm{Pb})$ and $\mathrm{Zinc}(\mathrm{Zn})$ on coral reefs and Foraminifera in Lampung bay waters.

\section{METHODS}

This study was conducted in December 2016 and January 2017. Sampling coral reefs and benthic of samples carried out in the Laboratory of Chemistry, Faculty of Mathematics and Natural Sciences, University of Lampung. 
Materials used in this study include samples of coral reefs and benthic foraminifera, aquabidest, concentrated Nitric acid (100\%) and the filter paper. The tools used in this study include laboratory glass tools, Plastic Ziplok, Dry Ice, Ice Box, GPS, Radio, Microscope, Analytical Balance with an accuracy of \pm 0.0001 grams, oven, centrifuge, and a set of ICP-OES ( inductively Coupled Plasma-Optical Emission Spectrometry) (Varian 715-ES).

The method used in this study is descriptive. Techniques of data retrieval is done by direct observation by direct observation in the field [5]. Stages in the research are:

\subsection{Sampling}

Sampling coral reefs and benthic Foraminifera carried out by using scuba or snorkeling in coastal waters ringgung sari, tegal island and the waters around the area Tarahan.

Table 1. Coordinates of sampling

\begin{tabular}{|c|c|c|}
\hline $\mathrm{No}$ & location & coordinates \\
\hline 1 & $\begin{array}{l}\text { Sari-ringgung } \\
\text { beach }\end{array}$ & $\begin{array}{l}\mathrm{S} 05^{0} 33^{\prime} 39.6 \\
\text { "E105 } 15^{0} 15^{\prime} 15.0^{\prime \prime}\end{array}$ \\
\hline 2 & Tegal Island & $\begin{array}{l}\mathrm{S} 05^{\mathrm{O}} 33^{\prime} 46.2 \\
\text { "E105 } 16^{\mathrm{U}} 38,5^{\prime}\end{array}$ \\
\hline 3 & Tarahan & $\begin{array}{l}\text { S } 05^{0} 31^{\prime} 11.7 \\
\text { "E105 } 20^{0} 42.7\end{array}$ \\
\hline
\end{tabular}

samples taken from the coral reefs of coral colonies were still numerous Foraminifera while samples taken from the sand around the coral reefs. Samples taken are put in a box of ice and placed into the refrigerator before getting started. Foraminifera done at some point Lampung coastal bays adjacent to the industrial plant. Preparation and analysis

\subsection{Preparation Material Test}

\subsubsection{Coral Reefs}

Coral reefs in the clean up first from salt water sea with distilled water (Milli-Q water) 3 times, to avoid contamination of trace elements of natural [6], [7]. Furthermore, coral reefs weighed a much as 2 grams each, the samples have been weighed in wearing the tube and add a solvent of nitric acid (100\%) until dissolved if it does not dissolve typically involves wet digestion in an oven with a temperature of $100 \%$, after a late diluted by adding aquabidest up to $25 \mathrm{ml}$ and centrifuge to separate the sediment carried by fitrat.

\subsubsection{Foraminifera}

Sand washed back on running water then dried, then performed the separation of Foraminifera sand under a microscope, then foraminifera samples each weighed as much as $2 \mathrm{~g}$, weighed sample is put in a test tube and added solvent concentrated nitric acid (100\%) until dissolved if it does not dissolve the wet destruction done in the oven with a temperature of $100^{0}$, after a late aquabidest diluted by adding up to $25 \mathrm{ml}$ and centrifuge to separate the sediment carried by fitrat.

\subsection{Analysis of Heavy Metal}

Samples were dissolved heavy metal content was analyzed using an ICP-OES (Inductively Coupled Plasma-Optical Emission Spectrometry) (Varian 715ES).

The parameters measured in this research that the levels of heavy metals ( $\mathrm{Ag}, \mathrm{Cd}, \mathrm{Co}, \mathrm{Cr}, \mathrm{Cu}, \mathrm{Fe}, \mathrm{Mn}$, $\mathrm{Ni}, \mathrm{Pb}, \mathrm{Zn}$ ) in the samples of coral reefs and benthic foraminifera from Lampung Gulf waters.

\section{RESULTS AND DISCUSSION}

\subsection{Heavy Metals In Coral Reef}

Based on the study content Heavy metal Cadmium, Cobalt, Chromium, Copper, Manganese, Iron, Nickel, Lead and Zinc in the samples, coral reef From the Coastal waters Sari Ringgung, island Tegal and Tarahan still are below the quality standards both in sediments laid down by Ministry of the Environment, ANZECC ISQG-Low, National Sediment Quality Survey USEP A and WAC 173-204-320 with a threshold value of each is shown in Table 3.

Heavy metals in samples that have exceeded the value of quality standards in sediment is Metal silver (Ag) in the samples taken from the coral reefs three places has exceeded the value of quality standards the sediment is determined on the DIY ( Daerah Istimewa Yogyakarta) Governor Regulation No. 7 of 2010 with a value of $0.1 \mathrm{mg} / \mathrm{kg}$. With the value of each - each Coral Ringgung $0.511 \mathrm{mg} / \mathrm{kg}$, Coral Reef tegal 0.106 $\mathrm{mg} / \mathrm{kg}$ and samples Coral Reef in the waters of Tarahan with a value of $0.217 \mathrm{mg} / \mathrm{kg}$. Thus shows the condition of Sediment in Lampung Bay waters is still in good condition.

However, if the results of the sample analyzed Coral Reef using quality raw Heavy Metals in the water used for biota only Cobalt Metal levels are still below the quality standard specified metal Menteri LH No. 5 of 2014 with a value of $0.4 \mathrm{mg} / \mathrm{kg}$. While the Heavy Metals others as follows: Metal Ag in samples of Sari Ringgung beach had higher levels of $0.511 \mathrm{mg} /$ $\mathrm{kg}$, on a sample of Tegal island $0.106 \mathrm{mg} / \mathrm{kg}$ and in samples from Tarahan had higher levels of $0.217 \mathrm{mg} /$ $\mathrm{kg}$ of the value has exceeded the quality standards of Metal Ag in sea water for biota set Menteri LH No. 5 in 2014 with the highest value of $0.5 \mathrm{mg} / \mathrm{kg}$. 
Table 2. The Average Heavy Metals In Coral Reef

\begin{tabular}{ccccccccccccc}
\hline No & Sample & \multicolumn{8}{c}{ Heavy Metal Concentration mg/kg } \\
\cline { 3 - 12 } & & $\mathbf{A g}$ & $\mathbf{C d}$ & $\mathbf{C o}$ & $\mathbf{C r}$ & $\mathbf{C u}$ & $\mathbf{F e}$ & $\mathbf{M n}$ & $\mathbf{N i}$ & $\mathbf{P b}$ & $\mathbf{Z n}$ \\
$\mathbf{1}$ & $\mathrm{C1}$ & 0,511 & 0,116 & 0,116 & 0,266 & 0,730 & 0,002 & 0,492 & 0,003 & 0,331 & 0,003 \\
$\mathbf{2}$ & C2 & 0,106 & 0,096 & 0,036 & 0,186 & 0,572 & 0,002 & 0,568 & 0,323 & 0,376 & 0,011 \\
\hline $\mathbf{3}$ & C3 & 0,217 & 0,105 & 0,075 & 0,124 & 0,782 & 0,844 & 0,511 & 0,359 & 0,000 & 0,017 \\
$\mathbf{4}$ & BM 1 & 0,100 & 2,500 & 50,000 & 80,000 & 62,000 & 20,000 & 120,000 & 80,000 & 50,000 & 410,000 \\
$\mathbf{5}$ & BM 2 & 0,500 & 0,001 & 0,400 & 0,005 & 0,008 & 0,500 & 0,100 & 0,005 & 0,008 & 0,005 \\
\hline
\end{tabular}

Description: C1 ( Coral Reef Ringgung), C2 (Coral Reef Tegal), C3 (Coral Reef Tarahan), BM 1 (Standard Quality Metals In Sediments), BM 2 (Standard Quality Metal In Sea Water for Biota)

Table 3. The Average Heavy Metals In foraminifera

\begin{tabular}{|c|c|c|c|c|c|c|c|c|c|c|c|}
\hline \multirow[t]{2}{*}{ No } & \multirow[t]{2}{*}{ Sample } & \multicolumn{10}{|c|}{ Heavy Metal Consentration $\mathrm{mg} / \mathrm{kg}$} \\
\hline & & $\overline{A g}$ & $\mathbf{C d}$ & Co & $\mathbf{C r}$ & $\mathrm{Cu}$ & $\mathrm{Fe}$ & Mn & $\mathbf{N i}$ & $\mathbf{P b}$ & $\mathbf{Z n}$ \\
\hline 1 & F1 & 0,250 & 0,101 & 0,226 & 0,001 & 0,549 & 0,238 & 0,011 & 0,010 & 0,001 & 0,002 \\
\hline 2 & $\mathrm{~F} 2$ & 0,161 & 0,046 & 0,077 & 0,466 & 0,662 & 0,071 & 0,012 & 0,276 & 0,416 & 0,002 \\
\hline 3 & F3 & 0,053 & 0,100 & 0,181 & 0,884 & 0,763 & 0,335 & 0,047 & 0,739 & 0,002 & 0,100 \\
\hline 4 & BM 1 & 0,100 & 2,500 & 50,000 & 80,000 & 62,000 & 20,000 & 120,000 & 80,000 & 50,000 & 410,000 \\
\hline 5 & BM 2 & 0,500 & 0,001 & 0,400 & 0,005 & 0,008 & 0,500 & 0,100 & 0,005 & 0,008 & 0,005 \\
\hline
\end{tabular}

$\mathrm{Ag}$ metal source derived from industrial and household waste in waters around. The impact of silver (Ag) for health, among others, if it accumulates in organs, will lead to pigmentation of gray (Argyria) [8]. The pigmentation of this nature is permanent, because the body cannot get rid of it. Ag can also cause skin irritations and discolor the skin (Argyria).

Metals cadmium $(\mathrm{Cd})$ in samples of coral reefs on the coast of Sari Ringgung have average $0.116 \mathrm{mg} / \mathrm{Kg}$, whereas from Tegal Island had higher levels of 0.096 $\mathrm{mg} / \mathrm{kg}$ and from Tarahan $0,105 \mathrm{mg} / \mathrm{kg}$. the figure has passed the quality standards of Metal Cd in seawater by Menteri LH No. 52014 with a maximum limit of 0.001 $\mathrm{mg} / \mathrm{kg}$. Mild cadmium poisoning can cause stomach nausea, vomiting, diarrhea, liver injury, shock and kidney failure. Symptoms of chronic cadmium poisoning are shortness of breath, decreased ability to smell, weight loss, tooth ache and golden brown.
Metal Chromium (Cr) in the samples of coral reefs inshore sari ringgung has an average level of $0,266 \mathrm{mg} / \mathrm{Kg}$ while the waters of the island tegal $0.186 \mathrm{mg} / \mathrm{kg}$ and in the waters of Tarahan 0.124 $\mathrm{mg} / \mathrm{kg}$. The value has passed the quality standard Metal Cr in Seawater determined by Menteri KLH No. 51/1/2004 with a value of $0.005 \mathrm{mg} / \mathrm{kg}$. Cr input source most of the activities of industrial, household activities and combustion [9]. The accumulation of metal chromium $(\mathrm{Cr})$ in the human body can cause damage to the body's organ systems. DHHS (depertmentof Health and Human Services), IARC( International Agency for Reseach on Cancer), andthe EPA ( Environmental Protection Agency ) established that chromium is a component of carcinogenic to human. 
Copper $(\mathrm{Cu})$ in the samples of coral reefs have average level of $0.730 \mathrm{mg} / \mathrm{kg}$, according to ANZECC ISQG-Low value content of $\mathrm{Cu}$ is still below the quality standard of Metal $\mathrm{Cu}$ in sediment with a value of $62 \mathrm{mg} / \mathrm{kg}$, but has passed the quality standard metal in sea water according to the Ministry of Environment No. $51 / 1 / 2004$.

Source $\mathrm{Cu}$ naturally derived from the events of erosion (erosion) mineral rocks, dust and particulate $\mathrm{Cu}$ in a layer of air, while the nonnaturally derived from human activities, among others from the shipbuilding industry, wood processing industry and household waste [10] Copper $(\mathrm{Cu})$ is a metal that is involved in the formation of energy for metabolism and the activity of tyrosine [11]. $\mathrm{Cu}$ deficiency is not uncommon in premature babies or babies with low weight. $\mathrm{Cu}$ deficiency can be caused by a number of $\mathrm{Cu}$ which is excreted through the urine. Symptoms of deficiency include decreased levels of $\mathrm{Cu}-\mathrm{Cu}$ and ceruloplasmin serum, anemia, skin depigmentation, matted hair, and brain damage [12]. Although it is needed by the body, $\mathrm{Cu}$ will turn into toxic material to humans when it enters the body copious amounts.

Samples Coral Reef in the waters of Tarahan has assay with an average of $0,844 \mathrm{mg} / \mathrm{kg}$ The value has exceeded the quality standards of $\mathrm{Fe}$ content in sea water for biota set by the USEPA (I986) with a value of $0.5 \mathrm{mg} / \mathrm{kg}$ whereas, samples from Sari Ringgung Beach and Tegal island still be below the quality standards $\mathrm{Fe}$ metal in sea water to biota. The high content of iron $(\mathrm{Fe})$ in the samples in the waters of Tarahan is because there are many waters around the factory or the disposal of iron corrosion that can occur and into the waters of the sea. Besides the source of ferrous metals can naturally occur from weathering of rocks are also derived from human activities that occur on land that household waste containing iron, the water reservoir of the iron deposits of industrial waste and the corrosion of water pipes containing ferrous metals brought river flow into the sea.

The high content of Fe metal will have an impact on human health of them can cause poisoning (vomiting), intestinal damage, premature aging to sudden death, arthritis, birth defects, bleeding gums, cancer, cirrhosis of the kidneys, constipation, diabetes, diarrhea, dizziness, tiredness, hepatitis, hypertension, insomnia [13].

Metal content of manganese (Mn) derived from the three sampling sites have passed the quality standard Heavy metals in sea water by the EPA
(Environmental Protection Agency) with a value of0.1 mg / kg. Heavy metal pollution in water can be derived from natural or industrial activities activities. Naturally the heavy metal pollution can result from the weathering on basin waters or the presence of volcanic activity [14]. Manganese metal pollution comes from ingredients active ingredient in batteries that have been used up and thrown into the river or the coast (Palar, 1994) [10]. Besides the source of manganese metal pollution from mines, mines channels atoms, microbes work against the mineral manganese in low $\mathrm{pE}$ [15].

Metal Nickel (Ni) in samples taken from waters Sari Ringgung still below the quality standard Nickel Metal values in seawater determined by the Minister of Environment No. 51/1/2004. While on samples taken from Water of Tarahan and Tegal island has passed the quality standard $\mathrm{Ni}$ metal (Table 3). Metals Pollution Nickel (Ni) from the air containing the combustion of fuel and coal combustion into the water through rain. Consumption of foods containing high concentrations of $\mathrm{Ni}$ metal and in the long term can lead to lung cancer, nasal cavity cancer, and cancer of the vocal cords, can even lead to death.

Metal Lead $(\mathrm{Pb})$ on the reef at all sampling locations have passed the quality standard metal in seawater by MEN KLH No. 51/1/2004 with a value of $0.008 \mathrm{mg} / \mathrm{kg}$. Heavy metals pollution sources in particular elements of $\mathrm{Pb}$ in part comes from industrial waste, household, and spill / leak fuel boat or ship. Lead poisoning is known as plumbisme more dangerous to children than adults. Lead tends to be concentrated in the bone. However, lead is stored in the form of a relatively inert causing no ill effects. If the body perceives the minerals calcium and phosphorus deficiency, blood not you release these minerals from the bone and passing it to the organs that need. In this process of lead becomes unstable and into the bloodstream. Furthermore, lead may be concentrated in the tissues resulting in toxic effects.

Zinc ( $\mathrm{Zn})$ metal on a coral reef at the beach site SariRinggung has a median levels - averaging $0.003 \mathrm{mg} / \mathrm{kg}$, the island of tegal $0.011 \mathrm{mg} / \mathrm{kg}$, aquatic tarahan $0.017 \mathrm{mg} / \mathrm{kg}$, on the location of the island and the Tarahan Tegal has gone through the standard Metal $\mathrm{Zn}$ on the quality of raw water for life while on site pantai sari ringgung were still under the limit of quality raw metals according to MEN KLH No. 51/1/2004 with a value of 0.005 $\mathrm{mg} / \mathrm{kg}$. 


\subsection{Heavy Metals in Foraminifera}

The analyzed of the sample Foraminifera in third place almost equal to sample the reef if in comparison with the quality standards of heavy metals in sediment, only metal Ag in Sari Ringgung beach and Tegal Island which has passed the quality standards set by the regulation DIY No. 7 of 2010 with a value of $0.1 \mathrm{mg} / \mathrm{kg}$ with a value of $0.250 \mathrm{mg} / \mathrm{kg}$, $0.161 \mathrm{mg} / \mathrm{kg}$ while the sample of Aquatic Tarahan is still below the quality standard. For other metals such as Cadmium, Chromium, Copper, Iron, Manganese, Nickel, Lead and Zinc in all samples remained below the quality standard metals in the sediment. The results of this study prove that the heavy metal content in the sediment in the bay of Lampung is still good.

However, if the results of the sample analysis Foraminifera use quality standard Heavy metals in the water used for biota only levels of metals cobalt, iron and manganese are still below the quality standard metal in Sea Water that is intended biota, while Heavy Metal intemperate quality standard Metals in Water between other Metals Silver, Cadmium, Chromium, Copper, Nickel, Lead and Zinc.

Metal Ag in samples of Sari Ringgung beach had higher levels of $0.250 \mathrm{mg} / \mathrm{kg}$, on a sample of Tegal Island $0.161 \mathrm{mg} / \mathrm{kg}$ and in samples from waters Tarahan levels of $0,053 \mathrm{mg} / \mathrm{kg}$ of the value has exceeded the quality standard metal $\mathrm{Ag}$ in ocean water for biota assigned the Minister of Environment No. 5 of 2014, with the highest value of $0.5 \mathrm{mg} / \mathrm{kg}$.

Metal cadmium (Cd) in the samples Foraminifera in coastal waters Sari Ringgung beach have an average $0.101 \mathrm{mg} / \mathrm{Kg}$, whereas from Tegal Island had higher levels of $0.046 \mathrm{mg} / \mathrm{kg}$ and from Waters Tarahan $0,1050 \mathrm{mg} / \mathrm{kg}$. the figure has passed the quality standards of Metal $\mathrm{Cd}$ in seawater for biota according to the Ministry of Environment No. 52014 with the maximum limit of $0.001 \mathrm{mg} / \mathrm{kg}$. Metal Chromium $(\mathrm{Cr})$ in samples of foraminifera Sari Ringgung coastal waters have an average rate of $0.001 \mathrm{mg} / \mathrm{Kg}$ is still under the raw quality of the waters of the island while in Tegal $0.466 \mathrm{mg} / \mathrm{kg}$ and in the waters of the Tarahan $0.884 \mathrm{mg} / \mathrm{kg}$. The value has passed the quality standard Metal $\mathrm{Cr}$ in Seawater determined by the Ministry of Environment No. 51/1/2004 with a value of $0.005 \mathrm{mg} / \mathrm{kg}$ of copper metal $(\mathrm{Cu})$ on Foraminifera from Ringgung Sari Beach location has an average level of $0.549 \mathrm{mg} / \mathrm{Kg}$ was still below the quality standards while at Tegal Island Aquatic $0.662 \mathrm{mg} / \mathrm{kg}$ and the water of Tarahan $0.763 \mathrm{mg} / \mathrm{kg}$ have passed the quality standard metals in sea water, according to the Ministry of Environment No. 51/1/2004 with a value of 0.008 $\mathrm{mg} / \mathrm{kg}$.

In samples taken from three locations Metal Nickel (Ni) has exceeded the value of the quality standard Nickel Metal in Seawater determined by the Minister of Environment No. 51/1/2004 with a value of 0.005 . The value of each sample at each location is $0,010 \mathrm{mg} / \mathrm{kg}, 0,276 \mathrm{mg} / \mathrm{kg}$ and 0.739 $\mathrm{mg} / \mathrm{kg}$.

Metals Lead $(\mathrm{Pb})$ in Foraminifera on the seaside location Sari Ringgung had higher levels of the average - average $0.001 \mathrm{mg} / \mathrm{kg}$, the island tegal $0.416 \mathrm{mg} / \mathrm{kg}$, water of Tarahan $0.002 \mathrm{mg} /$ $\mathrm{kg}$ only in Tegal Island locations that have passed quality standards metal $\mathrm{Pb}$ in sea water for life, while the other two locations are still below the quality standard limits according MEN KLH No. $51 / 1 / 2004$ with a value of $0.008 \mathrm{mg} / \mathrm{kg}$.

Metal Zinc (Zn) on Foraminifera on the seaside location Sari Ringgung had higher levels of the average - average $0.002 \mathrm{mg} / \mathrm{kg}$, the island tegal $0.002 \mathrm{mg} / \mathrm{kg}$, tarahan $0,100 \mathrm{mg} / \mathrm{kg}$ only in locations Tarahan who have passed the quality standard metal $\mathrm{Pb}$ in Water While marine biota second to another location is still below the quality standard limits according MEN metals KLH No. $51 / 1 / 2004$ with a value of $0.005 \mathrm{mg} / \mathrm{kg}$.

\subsection{Existence of Heavy Metals}

Overall from the study of heavy metals on coral reefs and foraminifera in the bay Lampung levels of heavy metals has exceeded the threshold value in the sediment is Metal Silver (Ag), Metal Iron $(\mathrm{Fe})$.

The existence of these metals can be caused by human activity and occur naturally. The sources of pollution in Lampung comes from industrial activities, such as agro-industry waste, activity pacing and shrimping boat. In addition, waste agriculture (pesticides and fertilizers), municipal waste, household waste and drainage water is another source of pollution. In Lampung are 160 units of domestic industry (Domestic Investment) and 33 industrial units FDI (Foreign Direct Investment). Does not rule out the possibility of heavy metals in the waters of the bay Lampung may come from outside the industry such Lampung waters of the bay of the island of Java and one because of drift and settles in the bay Lampung [15]. 


\section{CONCLUSIONS}

Based on the research that has been done can be concluded as follows:

1. The silver $(\mathrm{Ag})$ concentration in the coral reefs of all the points of study has exceeded the quality standards with the value of each is (0.42 mg/Kg), (0.19 mg/Kg ), (0.23 mg/Kg).

2. Both of $\mathrm{Ag}$ and Fe content in all Foraminifera samples exceed the value of quality standards.

\section{REFERENCES}

[1] Dahuri, R. Marine Biodiversity. Assets Sustainable Development Indonesia. PT Gramedia Pustaka Utama. 2003. Jakarta

[2] Haq. B. U. and Boersma. Introduction to Marine Micropaleontology. Elsevier Biomedical. 1983. New York

[3] Yanney. Ekologi Tropika. 2001. ITB. Bandung

[4] Nontji, A. Archipelago Sea Djambatan. 1993. Jakarta.

[5] Nazir, M. Metode Penelitian. Ghalia Indonesia. 1999. Jakarta

[6] Demina, L. L, Galkin, S. V, Shumilin, E. Bioaccumulation of some trace elements in the biota of the hydrothermal fields of the Guaymas Basin (Gulf of California). Boletín de la Sociedad Geológica Mexicana 61(1). 2009. Pp. 31
[7] Rentería-Cano, M.E., Sánchez-Velasco, L., Shumilin, E. Major and Trace Elements in Zooplankton from the Northern Gulf of California During Summer. Biol Trace Elem Res 142. 2011. Pp. 848-864

[8] Yulianto, B. Research Heavy Metal Pollution Level in Central Java North Coast. Research Reports, 2006. Research and Development. Province of Central Java.

[9] Palar, H. Pencemaran dan Roksikologi Logam Berat. 2004. Penerbit Rineka Cipta. p. 152

[10] Widowati., Sastiono., Jusuf. Efek Toksik Logam Pencegahan dan Penanggulangan Pencemaran. Andi Offset. 2008 Yogyakarta

[11] Heryando, P. Pencemaran dan Toksikologi Logam Berat. Rineka Cipta. 1994. Jakarta

[12] Linder, M. C. Biokimia Nutrisi dan Metabolisme. UI Press. 1992. Jakarta

[13] Parulian, A. Monitoring and Analysis Levels of Aluminum ( $\mathrm{Al}$ ) and iron $(\mathrm{Fe})$ On Drinking Water Treatment Tirtanadi Sunggaltaps. Terrain: 2009. Graduate University of North Sumatra (USU).

[14] Manahan, S.E. Environmental chemistry, Guide Book, Lewis Publisher Pakistan, No. 71, 1994. pp. 675-704.

[15] Nursusty. F., Atmodjo, W., and Hariyadi, H. Transpor Sedimen di Perairan Teluk Lampung. Journal of Oceanography. Vol.2. 2013. Pp. 361-368. 